\title{
Anxiety, a Psychoanalisis Study on Amory Blaine, the main character of This Side of Paradise, a novel by Francis Scott Fitzgerald
}

\author{
Farina D. Citrawati ${ }^{1 *}$, Nurdien H. Kistanto ${ }^{2}$ \\ 1,2 FIB Undip, Magister Ilmu Susastra (Master of English Literature), 50275 Jl. Prof. Soedharto, S.H. \\ Semarang, Central Java
}

\begin{abstract}
This Side of Paradise (first published in 1920) is the debut novel of Francis Scott Fitzgerald, the famous modern novelist in twentieth-century America. This novel is concerned with a modern industrial society that created a new culture that broke the tradition; one of the elements of this culture is the emergence of anxiety. This paper aims to describe the process of self-acceptance of Amory Blaine, the main character of This Side of Paradise. Amory Blaine faced anxiety in his early mature life as a part of the World War I aftermath. At the exact moment, many old American values should be broken. Using Sigmund Freud's Psychoanalysis theory, it was found that This Side of Paradise was the expression of the author's anxiety, Fitzgerald, when experiencing his self-acceptance. Anxiety is the main theme of this novel, besides the breaking tradition. This study applies a descriptive qualitative method that shows anxiety as a specific psychological disease in the modern industrial era, which correlates to the progress of industrial activities. The complexity of modern life has become a trigger for people living with anxiety. The undetected disease could also be a product of the anxious world. In this decade was what we named Covid-19 and its pandemic.
\end{abstract}

\section{Introduction}

It As Maclaughlin said, it seems to be an out to date thing to discuss the literature of a modernism era since we are in the post-postmodernism decade. The virtual borderline between the post-modernism era the post-modernism was the moment of the World Trade Centre's attack by two hijackers, MacLaughlin argued (MacLaughlin:2013). It will be a significant difference for non-speaking English country's students. Those who never live abroad need a specific understanding of each era in literature. Mostly English has no significant differences in grammar or dictions used in the manuscripts or other literary works. Even though they knew the history of Americans or English, it was hard to put into the meaning within the literary works. In order to have a comprehensive understanding of literature, it is essential to discuss the literary works from the Modernism era as a new start

* Nurdien H. Kistanto: nhkistanto@gmail.com 
of world-changing, while we are here in the post-postmodernism moment or virtual postmodernism era.

Defense Mechanism was still an excellent way to reveal the conflicts of the characters in literary works. Even we were in the post-postmodernism era. Alternatively, I preferred to mention that this era was Virtual-post modernism. Please take a look at a table that showed the defense Mechanism of Amory Blaine, the main character of This Side of Paradise (Fitzgerald:2012):

Table 1. Defense Mechanism of Amory Blaine.

\begin{tabular}{|c|c|}
\hline Repression & $\begin{array}{c}\text { contradictive } \\
\text { decisions }\end{array}$ \\
\hline $\begin{array}{l}\text { Projection/ } \\
\text { dis- } \\
\text { placement }\end{array}$ & $\begin{array}{c}\text { discontented } \\
\text { feeling of his } \\
\text { love to } \\
\text { Rosalind }\end{array}$ \\
\hline $\begin{array}{c}\text { Reaction } \\
\text { Formation } \\
\text { gave fault } \\
\text { example }\end{array}$ & $\begin{array}{c}\text { gosing people } \\
\text { he relied on }\end{array}$ \\
\hline Denial & $\begin{array}{c}\text { denying his } \\
\text { parents' belief } \\
\text { as Catholics }\end{array}$ \\
\hline
\end{tabular}

\section{DISCUSSION}

\subsection{Anxiety, a major reason why people defend themselves}

\subsubsection{Amory's anxiety}

Amory Through his character in This Side of Paradise, Amory Blaine told the world that anxiety could be a new culture of people in modern industrial society. As we know, that defense mechanism was a normal thing that happened to people. Using Psychoanalysis theory on Defense Mechanism, it could be revealed that the most reason which triggered people to defend themselves in many situations was their anxiety (Augustyn:2020).

Amory's life cases showed that the anxiety that happened to him was a misunderstanding of the actual situations. Starting in his early life, the mother did not explain in simple sentences about his morning arouse. He confessed that his mother was a beautiful one, but he did not have any attraction such a man with a woman. Instead of saying it was a normal phase of a boy, his mother spoke in the complex meaning of her saying. As in the sentences: "Dear, do not think of getting out of bed yet. I have always suspected that early rising in early life makes one nervous. Clothilde is having your breakfast brought up. " (Fitzgerald: 2012 p.).

Those conversations of the mother implied that she was from an upper-class woman. She said in orderly sentences with implicit meaning. However, the pure mind of a child was the same, either a child from the lower class or upper class. Even a boy was from a noble family, and the morning arose precisely happened to all boys. Why he always erected in the morning had no concise answer. 


\subsubsection{Results of Amory's anxieties}

From The table could also explain that he implicitly conflicted with himself because he could not occupy his anxious feeling. He should have repressed his belief in religion since his mother did not introduce him to church when he was in childhood. On the other hand, he enrolled in school where the basic curricula were religion when he was a juvenile, even though he went to school as his mother ordered, not himself who chose the school. Then being an atheist was such a break the tradition as their new beliefs (This Side of Paradise, Fitzgerald: 2012).

Furthermore, when his wealth faded away from his life because his parents passed away, he was in adult life. In the modernism era when Amory lived, everything was measured by the assets people had. It created an alcoholic habit when he lost Rosalind. Amory was not a rich man anymore. His alcoholic habit was just his reaction to escape the unhappy situation he faced (This Side of Paradise: 2012 p.69).

\subsection{Anxiety started from their own home}

Table 1 shows that the early Defense Mechanism (see on Reaction-Formation) of Amory was triggered by his mother in his childhood. His mother made him confused in understanding girls or women. He confessed that Beatrice was a very beautiful rich lady but he didn't get any Oedipus Complex; a man that fell in love with his mother. Reaction Formation that he did was his anxious feeling he had every time seeing a girl that he loved. His beautiful mother was complaining to the situation she faced by talking to him. Meanwhile he saw that his father was not with them. As a boy who still had pure feeling, he made conclusion of his parents' situation. It seemed that in his mind was female creature was the one who could make him attracted but at the same time she would trouble his life. It was why he must have kissed girls he fell in love with but to leave them (This Side of Paradise, Fitzgerald: 2012).

Table 2. Some results and conclusions of Amory's defense mechanism.

\begin{tabular}{|c|c|c|c|}
\hline $\begin{array}{c}\text { Defense } \\
\text { Mechanism }\end{array}$ & Triggers & Results & conclusions \\
\hline $\begin{array}{l}\text { Reaction - } \\
\text { formation }\end{array}$ & $\begin{array}{l}\text { His mother } \\
\text { gave fault } \\
\text { example of } \\
\text { being } \\
\text { woman }\end{array}$ & $\begin{array}{c}\text { Habit that he } \\
\text { didn't know } \\
\text { why he had } \\
\text { to kiss the } \\
\text { girls he was } \\
\text { attracted to } \\
\text { or he loved } \\
\text { to }\end{array}$ & $\begin{array}{l}\text { He became } \\
\text { anxious whenever } \\
\text { facing situations } \\
\text { which he couldn't } \\
\text { understand }\end{array}$ \\
\hline regression & $\begin{array}{l}\text { Losing } \\
\text { people he } \\
\text { relied on }\end{array}$ & $\begin{array}{c}\text { Being } \\
\text { childish and } \\
\text { looked so } \\
\text { depressed }\end{array}$ & $\begin{array}{l}\text { Anxieties } \\
\text { occupied his } \\
\text { mind. Losing his } \\
\text { confidence to } \\
\text { face life strongly. }\end{array}$ \\
\hline denial & $\begin{array}{l}\text { Denying } \\
\text { his } \\
\text { parents' } \\
\text { belief as } \\
\text { catholics }\end{array}$ & $\begin{array}{c}\text { Being atheist } \\
\text { as a new } \\
\text { belief }\end{array}$ & $\begin{array}{l}\text { breaking the } \\
\text { tradition; that } \\
\text { church was not } \\
\text { the answer to } \\
\text { solve the problem } \\
\text { in life }\end{array}$ \\
\hline
\end{tabular}




\subsection{Anxiety was a culture of modern industrial society}

The Amory's worst defence mechanism was when he faced a reality that he had to lose both of his parents. He was a rich boy with an upper-class social status people since he had not been born. He had to lose his wealth when he started his life as a mature man. Regression as his defensive mechanism was his great anxiety. As stated in the table that anxieties occupied his mind. He did not only lose his parents, but he also lost a big deal of his will of his parents. It did not happen to Amory Blaine himself (Fitzgerald:2012). The twentieth century as we know that it was a roaring twenties of the United States. The triumphant moments of the US in industries and technologies happened in this decade (Smart \& Kownslar:1987).

Since great demand toward the US as a super-power country, Americans seemed to chase and create their targets. This situation became a characteristic of modern industrial society. They put the high standard of their achievement. Anxiety became another culture of American people besides flappers for females and the Jazz age for the showbiz industry. The anxieties became new culture since the situations faced by people, especially in America. Those were the aftermaths of World War I, and soon after, there was World War II. Another effect of why anxiety became a culture was crash stock-market (Smart \& Kownslar:1987).

\subsubsection{World war I aftermath}

The aftermath of World War I that effect Amory was told that he quit his education at Princeton. It happened not long after his parents' death. Stephen and Beatrice left him with an enormous sum of debts they had. He broke without family around him. He took military service as a lieutenant. He made up his mind to be a soldier because he was alone in the world without family. He faced bankruptcy. If he died as a soldier, it would be much better. Died as a hero, not a poor man (This Side of Paradise, Fitzgerald: 2012, p184).

Despite being anxious about facing his future, he took the right pathway as a soldier. The War was over, and he went back to Princeton to continue his study. He could not make a clear vision of his life in the future. Tense situations were a condition faced by his generation. A world that people called the Modern era.

\subsubsection{Crash stock-market}

History of America wrote that the peak achievement of this country was in the twentieth century. They won World War. America posed itself as a creditor to the nations which took part in World War. Industries and technologies developed rapidly, as shown in the story of Stephen Blaine, Amory's father, why he became a wealthy man (This Side of Paradise, Fitzgerald: 2012). He was inherited from the death of the two brothers. They were wealthy brokers in New York. From then, Stephen and Beatrice, his wife, became a wealthy couple. They were both rich because of the stocks they had.

On the contrary, the period of his parents' life was contradictory to his. People in droves kept their money in stocks. Too many capitals triggered the collapse situation of the stock market. Their stocks had no value anymore. It led to what people called a crash-stock market. American people were anxious about their savings since they were almost all kept in stocks. Losing money and jobs as well was the situation that described the crash-stock market in America. In that situation, Amory Blaine lived. He was in an uncertain market. He almost lost all the wealth he got from his parents (This Side of Paradise, Fitzgerald: 2012, p142184). 


\subsection{World war II and the end of modernism era}

World World War II blasted from 1941 to 1945. America posted their winning time by the inventing of a bomb, a fusion reaction of nuclear. It was dropped to the two cities of Hiroshima and Nagasaki, Japan. America posed its country as a leader of the world, then. Actively, the roles of this country were all around the world. The United Nation sited the headquarter in New York, and it became the sign of the end of Modernism era.

Since then, America has become a centre point of the postmodern world. In which the pop culture led the civilization. As John Storey wrote in his article that popular culture is folk culture, something that arises from the people rather than imposed upon them: pop culture is authentic (created by the people) as opposed to commercial (thrust upon them by commercial enterprises) cited by Crossman (Crossman:2020).

\section{CONCLUSION}

\section{Anxiety was also a trigger of undetected disease like Covid - 19}

Drawing the line of what happened in the modernism era, the period where Amory lived into the facts nowadays, it seemed integrally correlated. Anxiety became a culture as represented in business : insurance businesses grew rapidly. Technologies to protect or safety devices were the product of anxiety. Many medicines were invented to cure the diseases that human's anxiety triggered the symptoms. Moreover, on the way around, the disease that was triggered by the anxiety also came up. Coronaviruses of nineteen years. This disease would attack humans quickly, to whom were anxious easily.

So, it could be concluded that the questions in life that had not been found the answers almost triggered our anxiety. As same as Covid-19, it was the disease that had not had the answer yet. What questions are they? It could be how to overcome the pollutions in the air, water, and especially oceans. Alternatively, the questions of how to preserve the earth from the garbage. And many more. Since all the questions were from humans, Covid -19 stopped them to think or rethinking all the humans' activities.

\section{References}

1. R.L. McLaughlin, After.the revolution : US post modernism. J. Narr. 3. 284-295(2013)

2. F. S. Fitzgerald, This side of paradise (2012)

3. A. Augustyn, Defense mechanism.encycl.britannica.com (2020)

4. F. S. Fitzgerald, This side of paradise . 69(2012)

5. J.L. Warner, The roaring twenties. The roaring 20's.google.com.web. (2020)

6. F. S. Fitzgerald, This side of paradise (2012)

7. F. S. Fitzgerald, This side of paradise (2012)

8. F. S. Fitzgerald, This side of paradise (2012)

9. T. L Smart, A. O. Kownslar, World history : A story of progress, (1987)

10. T. L Smart, A. O. Kownslar, World history : A story of progress, (1987)

11. F. S. Fitzgerald, This side of paradise (2012)

12. T. L Smart, A. O. Kownslar, World history : A story of progress, (1987)

13. F. S. Fitzgerald, This side of paradise (2012) 
14. A. Augustyn, Defense mechanism.encycl.britannica.com (2020)

15. A. Crossman, Sociological Definition of popular culture: The history and genesis of pop culture.Thought.Co.com. (2017) 